\title{
What weapons for what war?
}

The US Department of Defense is being given a predictably but understandably rough ride by the US Congress. It should prepare itself for the end of the Strategic Defense Initiative and should put the B2 bomber on ice.

THE usual case for building new weapons systems is that they may be needed in some future war, but that seems not strictly to apply to the B2 bomber over which the US Congress has been agonizing in the past few weeks. The aircraft is a remarkable exercise in high technology. Its chief characteristic, according to the US Air Force, is that it has a skin that makes it virtually undetectable by groundbased radar (presumably because the skin is made of organic materials that absorb rather than reflect at military radar frequencies), but it also has enormous range and carrying capacity - roughly a score of nuclear bombs. The cost of development so far is believed to exceed $\$ 22,000$ million. The need now is to decide whether to commit a further $\$ 4,000$ million for building the first of a planned fleet of 132 copies of the machine, the total cost of which will not be far short of $\$ 50,000$ million.

Understandably, given continuing anxiety about the US budget deficit, the high cost of the project seems at the front of most people's minds. Does it make sense to pay more than $\$ 400$ million for a single aircraft? The simple answer is that there is no absolute rule for telling what should be the cost of a military machine, but that, when large civil aircraft may sell on commercial markets for up to $\$ 200$ million, it is not entirely unreasonable that military aircraft, packed with handmade electronics, cost so much. The more serious issues are whether the procurement of the $\mathrm{B} 2$ is the most effective contribution to the security of the United States that might be secured for $\$ 50,000$ million and, whether, even if it were, the United States can afford such spending. The short answer is that the spending should be postponed until another year.

The fate of the B2 bomber will depend on the outcome of the bilateral START negotiations on strategic weapons just resumed at Geneva. There seems a good chance that the United States and the Soviet Union will reach an agreement that the numbers of strategic warheads deployed against each other should be reduced by roughly a half. The United States is working on the assumption that US nuclear forces will depend on the now-classic triad of land-based and submarine missiles and airborne warheads carried by bombers. But is that necessarily the case? In the past few weeks, the US Air Force has been giving members of the Congress unconvincing tales of how B2 bombers could be used in the wake of a substantial nuclear exchange to ensure that surviving hostile command posts are destroyed, which seems to have more bearing on the prosecution of nuclear war than on its deterrence.

If the outcome of the START negotiations is that the two major nuclear powers are restricted to roughly 2,500 nuclear warheads each, there will be a strong case for believing that the United States would be better placed with its eggs in two baskets only - submarine and landbased missiles. And the view of the US Air Force that Congress must buy at least a few examples of the aircraft so as to provide a bargaining counter at Geneva makes no sense. The $\$ 22,000$ million spent on development so far is a sufficient guarantor that the United States is serious about the B2. That is why the Congress should settle at this stage only for continued development, not procurement.

The Armed Services Committee of the House of Representatives has already voted in favour of reducing the cost of the Strategic Defense Initiative (SDI) for the financial year ahead to $\$ 1,600$ million - less than half what the administration had asked for. If that is the final outcome, it will imply that SDI lapses into a development programme, which is what it should have been all along. There seems no doubt that the START negotiations will not succeed without an undertaking that the Anti-Ballistic Missile Treaty is strictly interpreted, which would prevent the deployment of space-based weapons. Nobody will complain if the Pentagon thereafter continues to explore the potential of some of the schemes that were the objectives of SDI, but there is no case for doing more than that. And that conclusion should not be a matter for regret, but for rejoicing: like the Soviet Union, what the United States most stands to gain from arms control is relief from a haunting budget crisis.

\section{Using fetal tissue}

The British government has been given good advice on the conditions under which fetal tissue may be used.

LAST year's great fuss about the experimental use at a Birmingham hospital of transplanted fetal tissue for the treatment of parkinsonism should have been neatly laid to rest by the report of a committee under Dr John Polkinghorne, which appeared last week. The committee puts forward rules for the use of fetal material of all kinds that, while more restrictive than those now in force in 